\title{
Saúde, Religião e Trânsito Religioso: Estudo Pró-Saúde
}

\author{
Ana Paula Nunes ${ }^{1}$ \\ Cecília Mariz \\ Eduardo Faerstein ${ }^{1}$ \\ 1. Universidade do Estado do Rio de Janeiro (UERJ), Rio de Janeiro, RJ, Brasil. E-mail para \\ contato: ceciliamariz@globo.com.
}

\section{INTRODUÇÃO}

$\mathrm{O}$ s dados sobre identidade religiosa nos últimos censos demográficos brasileiros revelam que o perfil religioso da nossa população tem se modificado bastante. Estudos que analisam as dimensões sociais desse fenômeno apontam para uma forte relação entre diferentes identidades religiosas e nível de instrução, gênero, idade e regiões geográficas ${ }^{1}$. Com base na análise dos resultados de uma pesquisa de cunho epidemiológico (Estudo Pró-Saúde - EPS) que incluiu coleta de dados sobre religião atual e religião de criação, além de informações relacionadas ao perfil social e à saúde, o presente artigo pretende ampliar a compreensão da mudança de identidade religiosa, ou seja, do trânsito religioso, investigando as relações entre esse fenômeno e o estado de saúde dos indivíduos.

David Lehmann (2012) comenta que os grupos religiosos que mais crescem no Brasil, em outros países da América Latina e também na África são aqueles que oferecem crenças e práticas que ajudam a diminuir a dor e o sofrimento dos novos adeptos. Entre esses, o autor destaca, as igrejas pentecostais e neopentecostais que pregam o chamado Health and Wealth Gospel, traduzido no Brasil como "Teologia da Prosperidade" ${ }^{\prime 2}$. Nesse sentido, as religiões que por várias décadas conti-

DADOS - Revista de Ciências Sociais, Rio de Janeiro, vol. 59, no-4, 2016, pp. 1241 a 1274. 
nuam se expandindo nessas regiões podem ser identificadas como "cultos de aflição" (Fry e Howe, 1975). Lehmann (2012) argumenta ainda que cada vez mais os indivíduos vivem a religião como estratégia de superar sofrimento e ter esperança, o que tem afetado as próprias igrejas e religiões, de forma que essas não podem mais ser entendidas como uma questão de herança e tradição. A identidade religiosa enquanto opção individual tem sido questão muito debatida ${ }^{3}$ e tem levado a estudos que procuram explicar essa identidade pelas características do indivíduo. O texto de Lehmann (2012) nos estimula a considerar a busca de "bem-estar" ou saúde ${ }^{4}$ como uma dessas variáveis que afetariam a adoção de uma nova religião.

Neste artigo nos propomos, como já fizeram outros autores (Almeida e Montero, 2001; Fernandes e Pitta, 2006), identificar características dos sujeitos pesquisados que podem estar relacionadas com a rejeição da identidade religiosa familiar. Para ir além dos estudos acima citados, incluímos, entre essas características, a saúde. Na medida em que supomos que o abandono da religião de criação (e a decisão de ficar sem religião ou adotar uma nova), possa ser explicada pelo perfil social dos sujeitos e também por outras características, como seu estado de saúde, consideramos a religião neste trabalho como uma variável dependente, na contramão dos estudos epidemiológicos que tradicionalmente procuram investigar se as identidades ou práticas religiosas podem afetar a saúde (Koenig, 2001; Levin, 1996; Ellison, 1991; Pargament et al., 1988).

Doença e sofrimento sempre foram experiências importantes no discurso mágico religioso de todos os tempos. Análises da etimologia do termo central da tradição cristã, "salvação", têm apontado sua origem na ideia de saúde. As enfermidades levavam, como afirma Weber (2002:192), os indivíduos a buscarem magos e mistagogos para a sua solução ou, ao menos, justificativas e explicações para ele. No mundo contemporâneo, multiplicam-se as ofertas religiosas que ajudam a superar ou a lidar com sofrimentos, dores e doenças em geral. Para tanto, muitas religiões distinguem a doença material (ou física) da doença espiritual, propondo novos significados e terapias para esses males, como se pode verificar percorrendo uma ampla literatura (Montero, 1985; Minayo, 1988; Ferreti, 2003; entre outros). Com efeito, os grupos religiosos que mais têm crescido, segundo os diversos censos demográficos brasileiros, também se destacam por oferecer sistemas de cura alternativos: as igrejas pentecostais e o espiritismo kardecista. 
Pesquisas qualitativas realizadas em diversas partes do país, como as citadas a seguir, apontam para o fato de problemas de saúde estarem entre as principais razões e "aflições" que levam as pessoas a procurarem ajuda religiosa. As "curas" estão frequentemente presentes nos relatos de "conversão" ou adesão a uma nova fé, seja essa de cunho evangélico pentecostal (Neves, 1984; Mariz, 1994; Machado, 1996; Mafra, 2000, 2002; Medeiros, 2000; Bonfatti, 2000; Chesnut, 1997; entre muitos outros), seja uma religião mediúnica, como a espírita kardecista ${ }^{5}$ ou de outro tipo como os chamados "nova era" (ver Amaral, 2000, entre outros). A promessa de cura estaria também presente na fala dos líderes religiosos e nos seus rituais. Os centros espíritas se destacam como um sistema alternativo de saúde, sendo usual que os médiuns "recebam médicos desencarnados", como o famoso Dr. Fritz (fenômeno estudado por Lewgoy, 2004; Greenfield, 1992; entre outros). Nas igrejas pentecostais e neopentecostais, os cultos e ministérios de cura são bastante frequentes, e também são promovidos pelo Movimento de Renovação Carismática Católica (Carranza, 2000; Maués, 2004, Maués, Santos e Santos, 2002; Machado, 1996; Steil, 2004; Prandi,1996). O Health and Wealth Gospel, discurso religioso surgido nos EUA, ou a Teologia da Prosperidade, como referido anteriormente, se espalhou mundialmente por intermédio das igrejas evangélicas, especialmente as pentecostais e neopentecostais (Mariano, 1999; Freston, 1994).

A cura pelo sistema religioso tem especificidades que a distinguem daquela do sistema médico ocidental (Minayo, 1988; Luz, 2005). No primeiro sistema, a doença teria causas físicas/ morais/espirituais, portanto, para se obter saúde seriam necessárias intervenções em todos os aspectos da vida. Embora em vários grupos religiosos seja possível se submeter ao tratamento e processos de cura espiritual, sem necessariamente converter-se ou aderir totalmente às suas tradições religiosas, é comum que a superação ou alívio do problema requeira frequência constante ou resulte numa mudança de visão de mundo e, com o tempo na adoção de nova identidade religiosa. Estudos qualitativos sobre curas que ocorreram pela via religiosa indicam que na maior parte das vezes elas se dão de forma continuada exigindo do "curado" um novo estilo de vida e fidelidade ao grupo (Mariz, 1994). No pentecostalismo, tal como a chamada "libertação do alcoolismo" ou "superação da adição ao álcool", a "cura" em geral ocorre relacionada a mudanças no estilo de vida das pessoas e sua "conversão". Essas mudanças de hábitos cotidianos e até mesmo de círculos de amigos são acompanhadas tam- 
bém por uma transformação de visão de mundo e de reinterpretação dos acontecimentos da vida.

Portanto, este estudo orienta-se pela hipótese de que a tendência do indivíduo a abandonar a religião em que foi criado ou, pelo contrário, a permanecer nela, ou ainda a deixar de ter religião, poderia estar relacionada, não apenas a um perfil social específico, mas também a um enfrentamento cotidiano de problemas de saúde, que investigamos com a autopercepção dos indivíduos sobre seu estado de saúde.

A autopercepção de saúde tem sido extensamente utilizada em pesquisas epidemiológicas por revelar-se de alta robustez. Estudos longitudinais desenvolvidos desde a década de 1980 apontam que a autopercepção negativa de saúde, quando ajustada por outras variáveis (como idade, gênero, grau de "satisfação com a vida" e renda), tem demonstrado alta capacidade de predizer a mortalidade e morbidade em adultos (Quesnel-Vallée, 2007; Idler e Benyamini, 1997; Fonseca et al., 2008; Nunes, Barreto e Gonçalves, 2012). De fato, essa variável tem se revelado uma melhor preditora de mortalidade do que diversas medidas objetivas do estado de saúde, refletindo a percepção integrada e multidimensional do indivíduo ao incluir as dimensões biológicas, psicológicas e sociais da saúde (Idler e Benyamini, 1997; Martikainen, Arpo e Heliovaara, 1999; Bailis, 2003; Jylha et al., 1998; Martins, Barreto e Pordeus, 2009). Pessoas que relatam perceber a sua saúde como ruim apresentam maior risco de mortalidade por todas as causas em comparação com aquelas que relataram a sua saúde como boa (Kaplan e Camacho, 1983; Marcellini, 2002 e Guimarães et al., 2012). Adicionalmente, essa autoavaliação apresenta confiabilidade e validade equivalentes a outras medidas mais complexas ${ }^{6}$ da condição de saúde (Manderbacka, Lundberg e Martikainen, 1999).

É nossa proposta, por meio dos dados do EPS (pesquisa já citada), cuja construção e características serão analisadas no próximo item, alcançar os seguintes objetivos:

- Descrever o perfil social da população de estudo e, especificamente, dos participantes que já não possuem a identidade religiosa de criação (ou que experimentaram um trânsito religioso);

- Investigar a associação entre autopercepção de saúde e mudança de religião ou mudança para "sem religião", em comparação com a não mudança da identidade religiosa de criação. 


\section{METODOLOGIA}

No presente artigo, são analisados dados do Estudo Pró-Saúde (EPS), investigação epidemiológica longitudinal iniciada em 1999 com a população de trabalhadores técnico administrativos de campi universitários localizados no estado do Rio de Janeiro. Apesar de ser um estudo longitudinal, com coletas de dados conduzidas em 1999, 2001, 2006 e 2012, nossa análise se refere aos dados de 1999, quando houve a inclusão de perguntas sobre religião. Em nossa revisão de literatura, não encontramos, para o caso do Brasil, nem fontes nem bancos de dados que permitam, como faz o EPS, relacionar autopercepção de saúde com religião e trânsito religioso. Os dois outros artigos - Almeida e Montero (2001) e Fernandes e Pitta (2006) -, com os quais dialogamos analisam em âmbito nacional o trânsito religioso e sua relação com o perfil social, usam dados coletados mais ou menos no mesmo período dos dados do EPS. O primeiro artigo trabalha com dados de 1998 e o segundo com os dados de 2004.

Foram convidados a participar do EPS todos os funcionários técnico-administrativos em atividade, sendo considerados inelegíveis apenas aqueles cedidos a outras instituições ou licenciados por motivos não relacionados à saúde. A população elegível foi constituída por 4.459 funcionários, dos quais 4.030 (90,4\%) participaram da fase 1 do estudo em 1999.

Estratégias de divulgação do EPS incluíram matérias vinculadas na mídia interna, mensagens em contracheques e websites, cartazes e faixas. Além disso, foram enviadas cartas personalizadas aos domicílios dos funcionários, e realizadas visitas aos setores de trabalho. No caso de pessoas licenciadas por motivo de saúde, foram feitas visitas domiciliares.

A coleta de dados foi realizada por intermédio de questionários autopreenchíveis, com apoio de pesquisadores de campo e supervisores treinados. Para garantir a qualidade das etapas de coleta e processamento de dados, foram conduzidos pré-testes e um estudo piloto, estimativas de confiabilidade teste-reteste do instrumento e dupla digitação independente.

\section{Variável Dependente}

A variável trânsito religioso foi derivada da comparação entre as variáveis religião relatada em 1999 e religião de criação. Essas foram investiga- 
das, respectivamente, por meio das perguntas: "Atualmente, qual a sua religião?" e “Em que religião você foi criado(a)?". Foram relacionadas 18 religiões, "outra (especifique)" e "não tenho religião" ou "não fui criado em nenhuma religião".

Para o presente trabalho, as religiões foram categorizadas segundo os critérios do Instituto Brasileiro de Geografia e Estatística (IBGE):

- Afro-brasileira: Umbanda e Candomblé.

- Católica: Católica Apostólica Romana.

- Espírita Kardecista: Mediúnica Espírita.

- Pentecostais: Assembleia de Deus, Congregação Cristã do Brasil, Evangelho Quadrangular, Universal do Reino de Deus e Casa da Benção.

- Protestante Histórica: Adventista, Batista, Luterana, Metodista e Presbiteriana.

- Outras: Budista, Judaica, Messiânica, Testemunha de Jeová e outras especificadas pelos participantes.

- Sem religião/criado sem religião: não possui religião, ateu.

O trânsito religioso foi categorizado da seguinte maneira: "não mudou de religião" (NMR), "mudou para sem religião" (MpSR) e "mudou de religião" (MR). Esse tipo de categorização não leva em conta qual religião o indivíduo abandonou ou aderiu, mas busca apenas contabilizar quantos ainda se identificam com sua religião de criação, quantos a abandonaram por outra religião e quantos deixaram de ter qualquer religião.

\section{Variável Independente Principal}

A mensuração do estado de saúde foi realizada por meio da variável autopercepção da saúde construída a partir da pergunta "De um modo geral, em comparação a uma pessoa da sua idade, como você considera o seu próprio estado de saúde?", tendo as seguintes opções de resposta: muito bom, bom, regular e ruim. Para o presente estudo, a variável foi dicotomizada em bom (muito bom, bom) e ruim (regular e ruim).

\section{Variáveis Independentes de Controle}

A variável idade foi mensurada por meio da relação entre a data de nascimento do participante e a data da sua participação na pesquisa; fo- 
ram criadas cinco faixas etárias $(22-25 ; 26-40 ; 41-55 ; 56-65$ e >65). O cálculo da renda familiar per capita levou em consideração a renda familiar líquida de todas as pessoas que contribuíram regularmente para a despesa da casa no mês anterior à pesquisa e as pessoas que dependiam desse rendimento. Trabalhamos com os tercis da distribuição da renda mensal per capita em salários mínimos na época da entrevista através dos seguintes estratos: $<3,3-6$ e $>6,0$ salários mínimos. No questionário, a educação foi mensurada por meio de seis estratos com opções desde o 1ograu incompleto até a pós-graduação. Para fins desta análise a variável escolaridade foi categorizada em: até o fundamental completo, médio completo e universitário completo ou mais. O gênero foi incluído de forma usual (feminino, masculino). As variáveis estado civil (casado, separado, viúvo e solteiro), cor/raça autorreferida (branca, parda, preta e amarela/indígena) como também a renda foram utilizadas apenas para traçar o perfil da população não sendo incluídas nos modelos de regressão logística que serão detalhados na seção "Estratégia de análise".

\section{Investigações e Métodos de Análise}

Na seção "Perfil social e religioso da amostra", faremos a relação entre as variáveis sociodemográficas estratificadas por sexo (Tabela 1) e religião declarada em 1999 (Tabela 2). Na seção "Trânsito Religioso", propomos um fluxograma exploratório que descreve o trânsito entre as afiliações religiosas como também a "fidelidade religiosa" (ou seja, a não mudança de identidade religiosa). Para complementá-lo apresentamos a Tabela 4 que quantifica essa mobilidade. Na seção "Autopercepção da saúde e trânsito religioso" são apresentados os resultados das análises abaixo especificadas.

\section{Estratégia de Análise}

Com o modelo de regressão logística multinominal foi possível estimar (com intervalo de 95\% de confiança) a relação entre a autopercepção do estado de saúde (muito bom/bom e regular/ruim) e o trânsito religioso estratificado nas três categorias supracitadas (NMR, MpSR, MR). As associações da autopercepção regular/ruim da saúde no trânsito religioso são apresentadas na forma de razão de chances (RC) ajustadas pelas variáveis de potencial confundimento (sexo, idade e escolaridade). A RC identifica a chance de o evento ocorrer em um grupo em comparação com a chance de ocorrer em outro grupo de referência. 
A RC igual a 1 (um) indica que a condição ou evento sob estudo tem igual chance de ocorrer nos dois grupos, ou seja, revela ausência de associação estatística. Uma RC maior do que 1 indica que a condição ou evento tem maior chance de ocorrer no primeiro grupo do que no grupo de referência, representando então uma associação direta; uma razão de chances menor do que 1 indica que a chance de o evento ocorrer é menor no primeiro grupo do que no grupo de referência, caracterizando uma associação inversa. Nesse estudo investigamos se as pessoas que declararam perceber a sua saúde como regular/ruim teriam chances maiores $(R C>1)$, menores $(R C<1)$ ou iguais $(R C=1)$ de mudar ou perder totalmente uma identidade religiosa se comparadas a quem percebeu o seu estado de saúde como bom/muito bom, tomando-se como variáveis de controle sexo, idade e escolaridade. Para as análises utilizamos o pacote estatístico Stata, versão 11.0 (Stata Corporation, College Station, Estados Unidos).

\section{PERFIL SOCIODEMOGRÁFICO DA POPULAÇÃO DE ESTUDO}

Dos 4.030 funcionários técnico-administrativos investigados pelo EPS em 1999, 1.468 foram excluídos de nossas análises por faltarem dados relativos às principais variáveis de interesse (religião de criação ou religião em 1999), totalizando 2.562 participantes. Desse total, 1.961 eram mulheres (55\%), idade média de 40 anos (mínima de 22 anos e máxima de 81 anos), $52 \%$ de brancos autorrelatados e $60 \%$ de pessoas casadas. Observa-se ainda que os homens dessa população do estudo são mais jovens e menos instruídos do que as mulheres, o que pode explicar a maior proporção de homens no estrato de renda inferior (Tabela 1).

A população do EPS se distingue da população geral por algumas características importantes. Como Faerstein et al. (2005) salientam, trata-se de funcionários públicos, ou seja, indivíduos com emprego e renda assegurados, que não estão expostos a um importante fator de risco para a saúde que é a pressão emocional e social devida ao desemprego e/ou precariedade de vínculos empregatícios. Outra especificidade dessa amostra é o seu nível educacional. Há uma proporção elevada de indivíduos com nível superior (40\%) e apenas 15\% com grau de instrução até o nível fundamental completo, além da ausência de pessoas que não frequentaram escola. Esses dados contrastam com os números apresentados nos censos nacionais do IBGE que, no ano 2000 (ano seguinte a essa fase do EPS), indicam que 7\% da população brasileira, com 25 anos ou mais de idade, teriam nível superior enquanto $64 \%$ 
Tabela 1

Características Sociodemográficas da População de Estudo

\begin{tabular}{|c|c|c|c|}
\hline & $\begin{array}{c}\text { Homens } \\
\text { n (\%) }\end{array}$ & $\begin{array}{c}\text { Mulheres } \\
\text { n (\%) }\end{array}$ & $\begin{array}{l}\text { Total } \\
\text { n (\%) }\end{array}$ \\
\hline \multicolumn{4}{|l|}{ Idade } \\
\hline $22-25$ & $46(2,9)$ & $37(1,9)$ & $90(2,3)$ \\
\hline $26-40$ & $879(54,9)$ & $989(50,4)$ & $1.854(52,4)$ \\
\hline $41-55$ & $595(37,1)$ & $823(41,9)$ & $1.418(39,8)$ \\
\hline $56-65$ & $69(4,3)$ & $107(5,5)$ & $181(5,0)$ \\
\hline$>65$ & $12(0,8)$ & $5(0,3)$ & $19(0,5)$ \\
\hline \multicolumn{4}{|l|}{ Cor/raça autodeclarada } \\
\hline Branca & $848(53,0)$ & $1.015(51,8)$ & $1.862(52,3)$ \\
\hline Parda & $512(32,0)$ & $537(27,4)$ & $1.047(29,4)$ \\
\hline Preta & $198(12,4)$ & $358(18,3)$ & $560(15,7)$ \\
\hline Amarela/indígena & $43(2,6)$ & $51(2,5)$ & $93(2,6)$ \\
\hline \multicolumn{4}{|l|}{ Estado civil } \\
\hline Casado & $1.119(69,9)$ & $1.055(53,8)$ & $2.173(61,0)$ \\
\hline Separado & $162(10,1)$ & $372(19,9)$ & $553(15,5)$ \\
\hline Viúvo & $14(0,9)$ & $90(4,6)$ & $106(3,0)$ \\
\hline Solteiro & $306(19,1)$ & $444(21,7)$ & $730(20,5)$ \\
\hline \multicolumn{4}{|l|}{ Escolaridade } \\
\hline Até o fundamental completo & $292(18,2)$ & $229(11,7)$ & $521(14,6)$ \\
\hline Médio completo & $783(48,9)$ & $823(41,9)$ & $1.602(45,0)$ \\
\hline Universitário completo ou mais & $526(32,9)$ & $909(46,4)$ & $1.439(40,4)$ \\
\hline \multicolumn{4}{|c|}{ Renda mensal per capita (em salários mínimos)* } \\
\hline$<3,0$ & $517(32,3)$ & $461(23,5)$ & $975(27,5)$ \\
\hline $3,0-6,0$ & $571(35,7)$ & $737(37,6)$ & $1.308(36,7)$ \\
\hline$>6,0$ & $513(32,0)$ & $763(38,9)$ & $1.279(35,8)$ \\
\hline \multicolumn{4}{|l|}{ Religião em 1999} \\
\hline Sem religião & $251(15,7)$ & $176(9,0)$ & $427(12,1)$ \\
\hline Católica & $809(50,5)$ & $955(48,7)$ & $1.764(49,5)$ \\
\hline Pentecostal & $111(6,9)$ & $108(5,5)$ & $216(6,1)$ \\
\hline Protestante histórico & $120(7,5)$ & $177(9,0)$ & $295(8,3)$ \\
\hline Espírita kardecista & $153(9,6)$ & $300(15,3)$ & $455(12,8)$ \\
\hline Afro-brasileira & $64(4,1)$ & $90(4,7)$ & $157(4,4)$ \\
\hline Outras & $93(5,7)$ & $155(7,8)$ & $248(6,8)$ \\
\hline
\end{tabular}


Características Sociodemográficas da População de Estudo

\begin{tabular}{l|ccc}
\hline & $\begin{array}{c}\text { Homens } \\
\mathbf{n ~ ( \% )}\end{array}$ & $\begin{array}{c}\text { Mulheres } \\
\mathbf{n ~ ( \% )}\end{array}$ & $\begin{array}{c}\text { Total } \\
\mathbf{n}(\mathbf{\%})\end{array}$ \\
\hline Religião que foi criado(a) & & & \\
$\quad$ Sem religião & $98(6,2)$ & $70(3,6)$ & $167(4,7)$ \\
Católica & $1.219(76,2)$ & $1.565(79,8)$ & $2.785(78,2)$ \\
Pentecostal & $53(3,3)$ & $46(2,3)$ & $99(2,8)$ \\
Protestantismo histórico & $103(6,5)$ & $115(5,8)$ & $213(6,0)$ \\
Espírita kardecista & $41(2,6)$ & $51(2,6)$ & $92(2,6)$ \\
Afro-brasileira & $55(3,4)$ & $67(3,5)$ & $121(3,4)$ \\
Outras & $32(1,8)$ & $47(2,4)$ & $85(2,3)$ \\
\hline Total & $\mathbf{1 . 6 0 1 ( 1 0 0 , 0 )}$ & $\mathbf{1 . 9 6 1 ( 1 0 0 , 0 )}$ & 3.562 \\
\hline
\end{tabular}

Fonte: Elaboração própria a partir do Estudo Pró-Saúde (1999).

* Valor do salário mínimo na época da pesquisa R\$136,00.

declararam possuir "fundamental incompleto ou sem instrução". Tais especificidades não constituem um problema para nossa análise, pois o objetivo desse artigo não é propor inferências para outros universos populacionais, mas observar associações entre algumas variáveis de forma controlada nesse conjunto populacional naquele determinado momento. No entanto, essas características da população de estudo do EPS influenciam o seu perfil religioso, o que fica evidente quando se compara com os dados observados na sociedade brasileira como um todo à mesma época da pesquisa (anos 1999 e 2000).

No censo de 2000, 74\% dos brasileiros declararam-se católicos, 15\% eram evangélicos, $7 \%$ sem religião, e os kardecistas eram apenas 1\% da população. No EPS os católicos não chegam à metade dos pesquisados (49\%) tornando essa amostra diferenciada em relação não apenas à população brasileira, mas também à da cidade do Rio de Janeiro ${ }^{4}$. Outra característica distintiva é a baixa proporção de pentecostais, que depois da católica é a identidade religiosa mais declarada no Brasil e no Rio de Janeiro em ambos os censos (2000 e 2010). Já na amostra do EPS os percentuais de espíritas kardecistas e dos que se declaram "sem religião" alcançaram $13 \%$ e $12 \%$ respectivamente, aproximadamente o dobro dos pentecostais que constituem apenas $6 \%$ dessa amostra.

Como já tem sido muito discutido pela literatura sobre religião no Brasil e em especial por estudos apoiados nos dados dos censos ${ }^{7}$, há uma 
forte associação entre nível educacional e identidade religiosa declarada (Teixeira e Menezes, 2006; Teixeira, 2013). Dessa forma, o elevado nível de instrução faz com que nossa amostra possua um perfil religioso distinto da sociedade mais ampla. No EPS, a segunda e terceira categorias de identidade religiosa mais frequentemente declaradas, "espírita kardecista" e "sem religião", possuem as maiores proporções de pessoas com "universitário completo ou mais", $54 \%$ e $40 \%$ respectivamente (Tabela 2). Diferentes autores já discutiram a relação entre uma instrução mais elevada no Brasil e o Kardecismo, mostrando como práticas e crenças kardecistas enfatizam a leitura e valorizam discursos considerados lógicos e "racionais" (ver, entre outros, Aubrée e Laplantine, 2009). Observa-se ainda que a categoria "espíritas kardecistas" é aquela com maior percentual de brancos.

Os protestantes históricos formam o quarto maior grupo na população do EPS (8\%), sendo composto majoritariamente por pessoas com o ensino médio completo (Tabela 2). Para entendermos a importância do nível educacional na identidade de grupo religioso é importante comparar com o percentual total desta população: enquanto $52 \%$ dos protestantes históricos têm o ensino médio completo (Tabela 2), no total da amostra $45 \%$ têm esse nível de instrução (Tabela 1).

Os pentecostais, cuja presença supera apenas a dos que declararam pertencer a religiões afro-brasileiras, possuem os níveis mais baixos de escolaridade e renda da amostra além de serem "menos brancos" (Tabela 2). Há mais brancos entre os que declaram religiões afro-brasileiras $(41 \%)$ do que entre os pentecostais $(32 \%)^{8}$. Em relação ao nível de instrução observa-se que enquanto na amostra total há $40 \%$ com nível "universitário completo ou mais", entre os pentecostais apenas $10 \%$ têm esse nível de instrução. Por outro lado, $40 \%$ dos pentecostais possuem apenas o fundamental completo enquanto no total dessa amostra aproximadamente 15\% está na mesma situação (comparação da Tabela 1 com a Tabela 2).

O perfil educacional de nossa população de estudo tem ainda um reflexo - menor, mas igualmente importante - na declaração sobre a religião em que o participante foi criado. Numa população de alto nível educacional, os pais também tendem a ter educação elevada (Ribeiro, 2011) e, por sua vez, o grau de instrução dos pais se reflete na religião na qual os entrevistados foram criados. Ao cotejarmos as religiões de criação declaradas com os dados dos censos de 1970 e 1980, época 


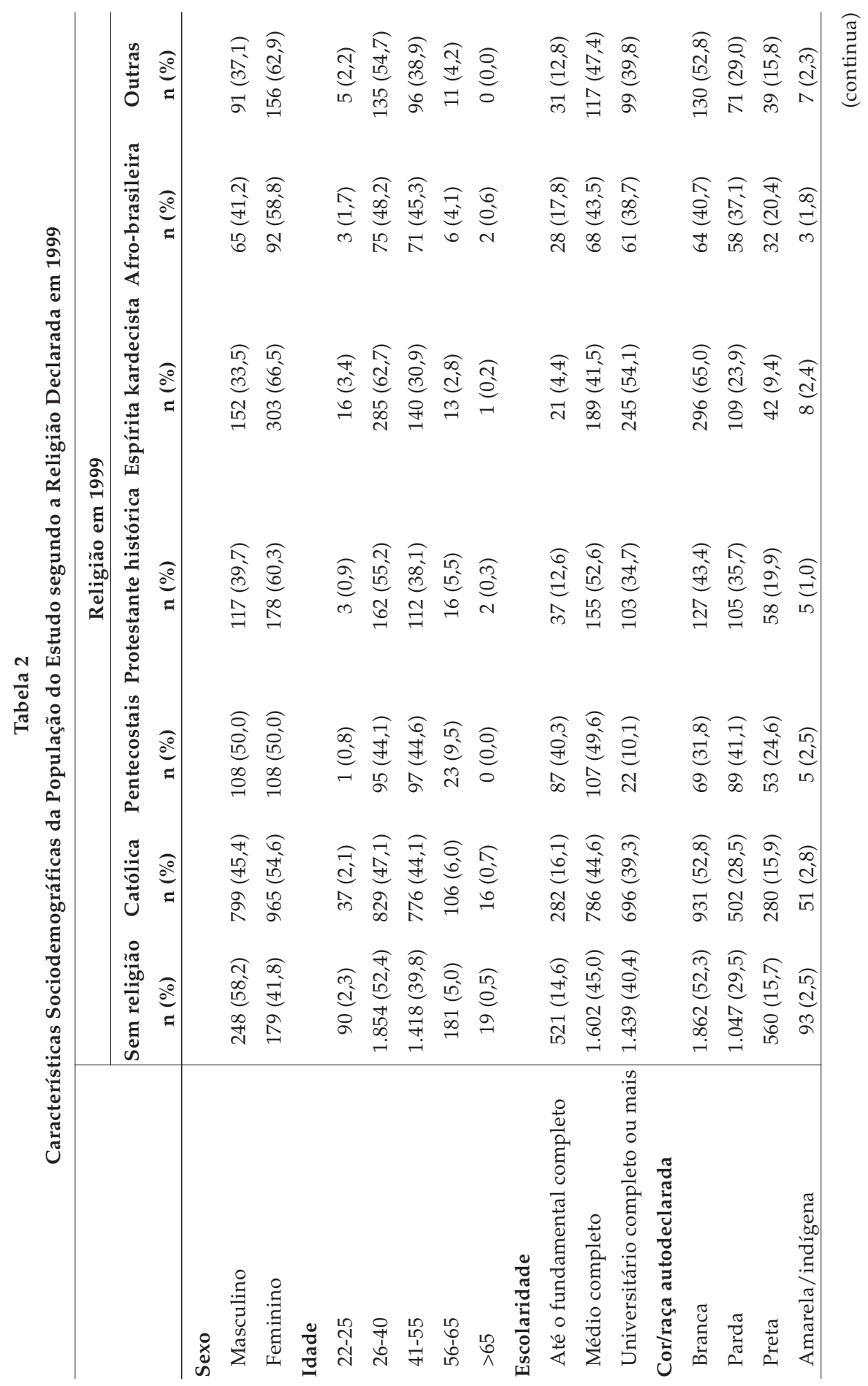

1252 DADOS - Revista de Ciências Sociais, Rio de Janeiro, vol. 59, no 4, 2016 


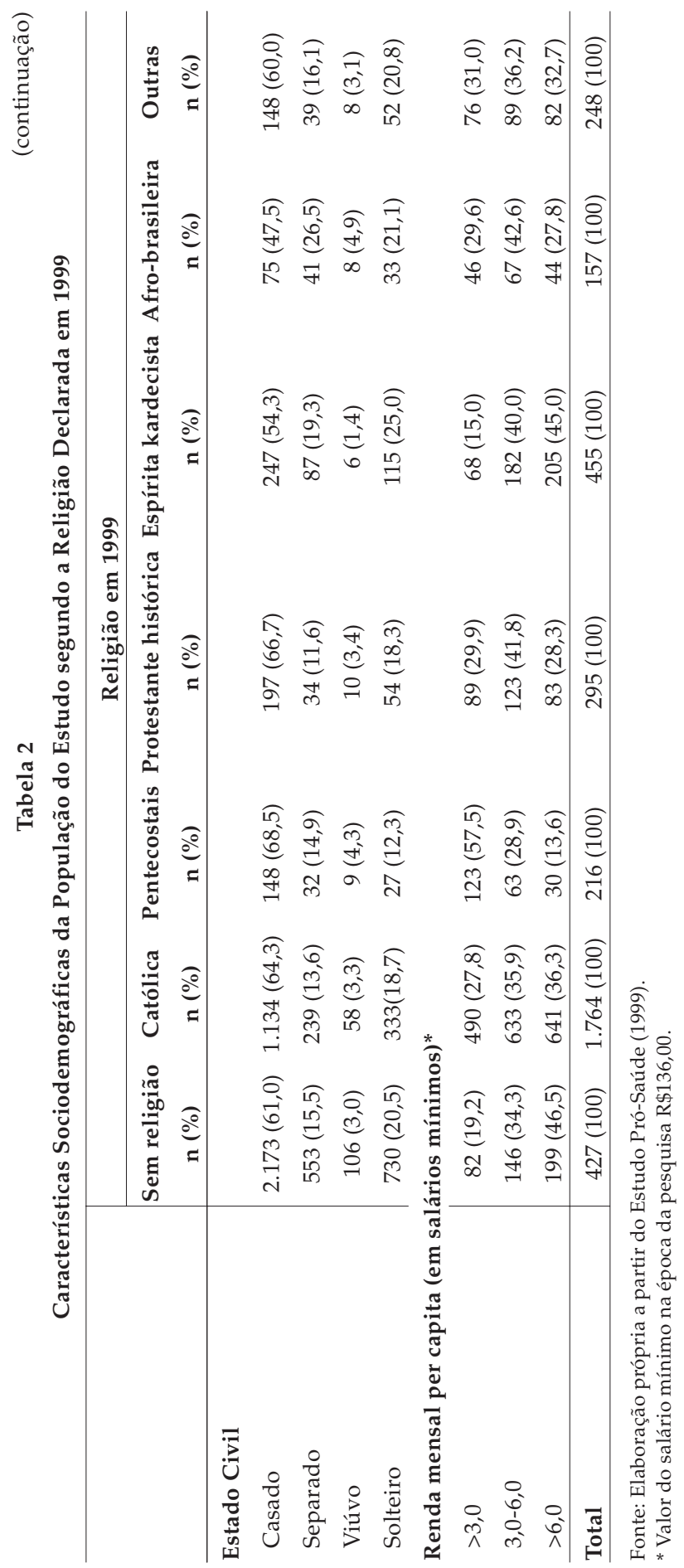


provável da infância de mais da metade dos pesquisados, notamos, por exemplo, uma proporção pequena de entrevistados que declaram ter sido criados em confissões pentecostais relativamente à totalidade de pentecostais naquelas décadas no Brasil e no Rio de Janeiro, especificamente.

Embora o gênero seja uma variável importante no estudo da religião, como assinala com frequência a literatura nacional e internacional ${ }^{9}$, no EPS a associação entre o gênero dos pesquisados e sua identidade religiosa e religião de criação parece ter sido afetada pelo fato de as mulheres serem mais velhas e mais instruídas do que os homens. A mais baixa instrução dos homens pode explicar porque há relativamente mais homens criados nas religiões pentecostais (Tabela 2) e proporcionalmente mais homens no total da população pentecostal do que havia homens na amostra como um todo (Tabela 1). O fato dos homens serem mais jovens explicaria não apenas uma tendência maior de homens terem sido criados "sem religião" e "pentecostais" (Tabela 2), mas ainda se declararem "sem religião". Com efeito, há forte associação entre a declaração de sem religião e juventude, como mostra Novaes (2013) em sua análise do censo de 2010.

\section{TRÂNSITO RELIGIOSO}

Podemos avaliar o trânsito religioso comparando a religião declarada em 1999 com aquela em que se foi criado(a). Nota-se que 38\% dessa amostra não se identificam mais com a religião de criação, o que significa uma intensa mobilidade religiosa que se revela um pouco superior ao que foi observado pelos outros dois estudos sobre trânsito religioso, já citados, referentes à população nacional realizados mais ou menos à mesma época ${ }^{10}$. A parcela que declara não possuir mais a identidade religiosa em que foi criada é formada por dois segmentos bem distintos: o maior, que adotou uma nova identidade religiosa ( $26 \%$ ) e um menor, que passou a se referir como "sem religião" (12\%).

A Tabela 3 permite entender melhor o trânsito religioso: o perfil social do segmento que mantém a identidade religiosa em que foi criado, ou seja, "não mudou de religião" (NMR) é muito similar ao total da amostra. O grupo que "mudou de religião" (MR) foi formado na sua maioria por mulheres, com escolaridade relativamente mais baixa (até o ensino fundamental completo ou médio completo) e com uma renda familiar menor que 6 salários mínimos per capita. O segmento formado pelos 
Saúde, Religião e Trânsito Religioso: Estudo Pró-Saúde

Tabela 3

Características Sociodemográfico da População do Estudo em relação ao Trânsito Religioso

\begin{tabular}{|c|c|c|c|c|}
\hline & $\begin{array}{l}\text { Não Mudou } \\
\text { de Religião } \\
\text { n (\%) }\end{array}$ & $\begin{array}{c}\text { Mudou para } \\
\text { Sem Religião } \\
\text { n (\%) }\end{array}$ & $\begin{array}{l}\text { Mudou de } \\
\text { Religião } \\
\text { n (\%) }\end{array}$ & $\begin{array}{l}\text { Total } \\
\text { n (\%) }\end{array}$ \\
\hline \multicolumn{5}{|l|}{ Sexo } \\
\hline Masculino & $1.015(46,0)$ & $234(56,7)$ & $350(37,3)$ & $1.601(45,0)$ \\
\hline Feminino & $1.193(54,0)$ & $179(43,3)$ & $586(62,7)$ & $1.961(55,0)$ \\
\hline \multicolumn{5}{|l|}{ Idade } \\
\hline $22-25$ & $53(2,5)$ & $18(4,5)$ & $14(1,5)$ & $90(2,3)$ \\
\hline $26-40$ & $1.055(47,8)$ & $263(63,9)$ & $508(54,3)$ & $1.854(52,4)$ \\
\hline $41-55$ & $957(43,1)$ & $122(29,6)$ & $357(38,1)$ & $1.418(39,8)$ \\
\hline $56-65$ & $130(5,9)$ & $7(1,7)$ & $51(5,5)$ & $181(5,0)$ \\
\hline$>65$ & $13(0,7)$ & $1(0,3)$ & $4(0,5)$ & $19(0,5)$ \\
\hline \multicolumn{5}{|l|}{ Raça } \\
\hline Branca & $1.181(53,5)$ & $246(59,7)$ & $468(50,1)$ & $1.862(52,6)$ \\
\hline Parda & $640(29,0)$ & $105(25,6)$ & $282(30,2)$ & $1047(29,4)$ \\
\hline Preta & $334(15,1)$ & $50(12,2)$ & $165(17,6)$ & $560(15,7)$ \\
\hline Amarela/indígena & $53(2,4)$ & $10(2,5)$ & $19(2,1)$ & $93(2,5)$ \\
\hline \multicolumn{5}{|l|}{ Estado civil } \\
\hline Casado & $1.414(64,0)$ & $212(51,5)$ & $547(58,5)$ & $2.173(61,0)$ \\
\hline Separado & $291(13,2)$ & $69(16,8)$ & $182(19,5)$ & $553(15,5)$ \\
\hline Viúvo & $75(3,4)$ & $6(1,5)$ & $29(2,8)$ & $106(3,0)$ \\
\hline Solteiro & $428(19,4)$ & $124(30,2)$ & $178(19,2)$ & $730(20,5)$ \\
\hline \multicolumn{5}{|l|}{ Escolaridade } \\
\hline Fundamental completo & $359(16,3)$ & $25(6,2)$ & $155(16,6)$ & $521(14,6)$ \\
\hline Médio completo & $964(43,6)$ & $171(41,6)$ & $452(48,1)$ & $1.602(45,0)$ \\
\hline Universitário completo & $885(40,1)$ & $215(52,2)$ & $329(35,3)$ & $1.439(40,4)$ \\
\hline
\end{tabular}

Renda mensal per capita (em salários mínimos)*

\begin{tabular}{|c|c|c|c|c|}
\hline$<3,0$ & $591(26,8)$ & $72(17,5)$ & $289(30,8)$ & $975(27,5)$ \\
\hline $3,0-6,0$ & $798(36,1)$ & $142(34,2)$ & $362(38,7)$ & $1.308(36,7)$ \\
\hline$>6,0$ & $819(37,1)$ & $199(48,3)$ & $285(30,5)$ & $1.279(35,8)$ \\
\hline Total & $2.208(62,1)$ & $413(11,6)$ & $936(26,3)$ & $3.562(100,0)$ \\
\hline
\end{tabular}

Fonte: Elaboração própria a partir do Estudo Pró-Saúde (1999).

* Valor do salário mínimo na época da pesquisa R $\$ 136,00$. 
que "mudaram para sem religião" (MpSR), foi majoritariamente masculino, mais jovem e mais instruído.

Outra informação importante para um melhor entendimento do trânsito religioso diz respeito aos trajetos específicos, ou seja, quais religiões foram abandonadas e quais foram adotadas, o que pode ser observado na Tabela 4 e no fluxograma (Figura 1) similares aos já elaborados por Almeida e Montero (2001) e Fernandes e Pitta (2006).

Tanto entre os indivíduos pesquisados quanto na população brasileira no mesmo período (segundo informam os censos já mencionados), a religião católica perdeu maior número de adeptos. Enquanto $78 \%$ dos participantes declararam terem sido criados como católicos, apenas $49 \%$ se identificavam com essa religião em 1999. A religião católica foi a única que perdeu fiéis - todas as demais cresceram. No entanto, quando analisamos a fidelidade religiosa (ou seja a proporção daqueles que continuam na religião em que foram criados), observamos que esta é maior entre os espíritas kardecistas (66\%), seguidos por católicos $(64 \%)$, protestantes históricos (63\%) e pentecostais (57\%). O grupo de menor fidelidade seria o de religiões afro-brasileiras (37\%) tendo sido esse grupo ultrapassado pelos criados sem religião. Entre os criados sem religião, 41\% continuavam sem religião (Tabela 3 ).

Dessa forma, observa-se que apesar de a Igreja Católica perder grande número de fiéis no cômputo geral, essa perda não parece ser explicável, na população aqui estudada, simplesmente por uma incapacidade de manter seus fiéis, mas pela incapacidade de atrair novos seguidores. Esse argumento parece claro quando observamos que a duplicação de fiéis pentecostais não vem acompanhada por uma alta taxa de fidelidade mas, pelo contrário, por uma das mais baixas. Ou seja, a perda de adeptos entre os católicos parece haver ocorrido por uma incapacidade da Igreja Católica de atrair novos fiéis; as igrejas pentecostais, apesar de perderem mais seguidores, teriam maior capacidade de atrair novas adesões.

Entre os pesquisados que afirmam ter abandonado a religião na qual foram criados, $12 \%$ se tornaram pentecostais e $11 \%$ protestantes históricos. Se considerarmos esses grupos como uma única categoria - os evangélicos -, o resultado seria um crescimento de $23 \%$ para esta categoria. Apesar de superar os percentuais dos que aderiram às religiões afro-brasileiras $(6 \%)$, à católica $(6 \%)$ e a um conjunto misto de outras religiões (14\%), a proporção dos que se tornaram evangélicos é menor 


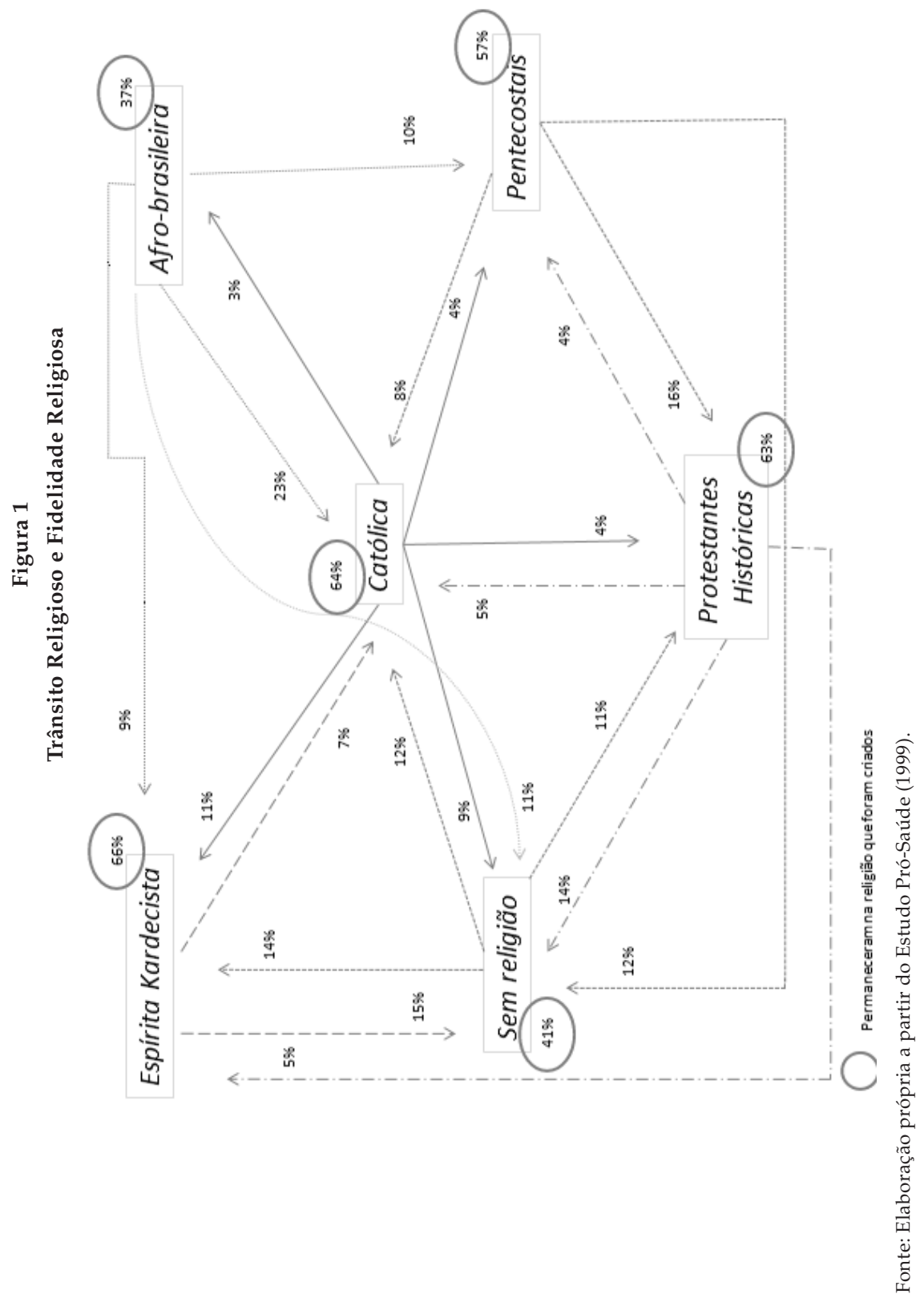




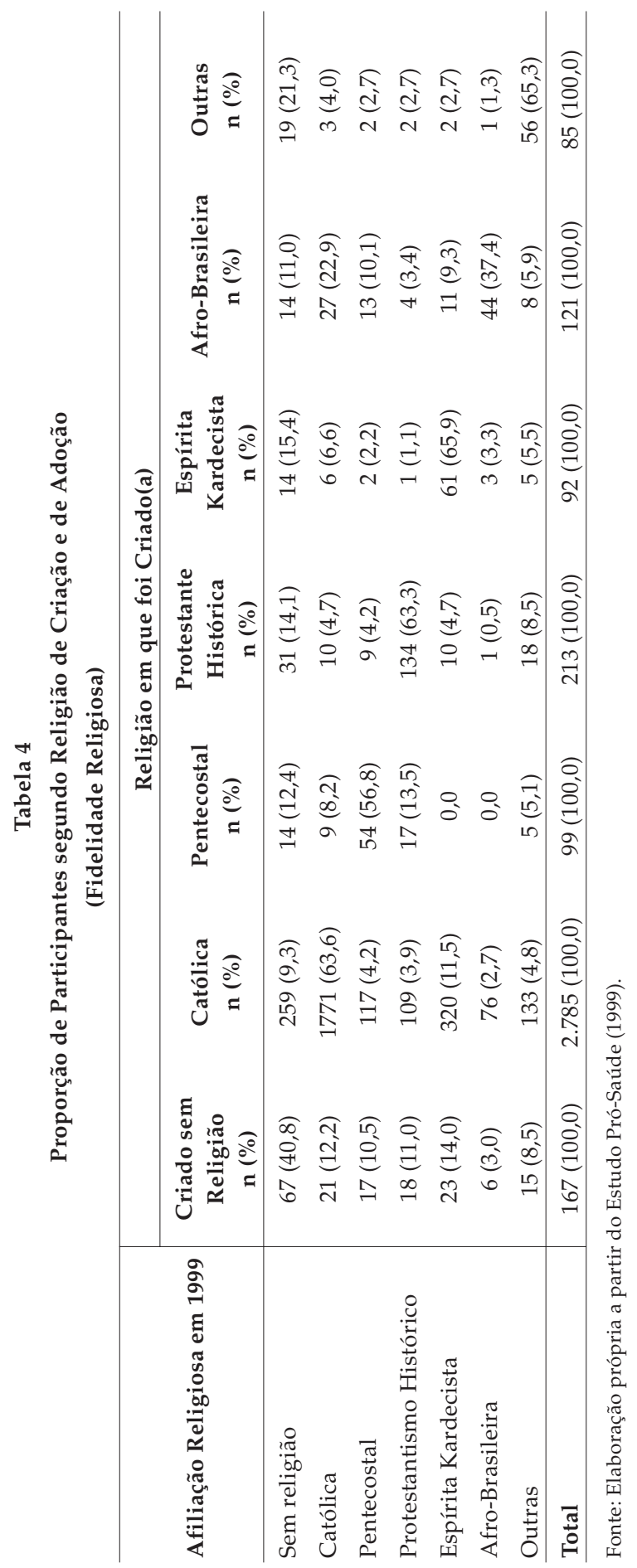

1258 DADOS - Revista de Ciências Sociais, Rio de Janeiro, vol. 59, no 4, 2016 
do que os $27 \%$ que se tornaram kardecistas como também menor do que os 25\% que deixaram de ter religião. O trânsito religioso observado nessa amostra, marcado por um preponderante crescimento de espíritas kardecistas e dos sem religião, se distingue daquele descrito por estudos baseados em amostras com representatividade nacional, tais como o Almeida e Montero (2001) e o de Fernandes e Pitta (2006).

A Tabela 5 indica apenas os que deixaram a religião em que foram criados, relacionando-os com a religião que declaravam ter à época da pesquisa. Essa tabela segue o modelo adotado por outros autores já citados (Almeida e Montero, 2001; Fernandes e Pitta, 2006).

Ainda observamos que nesse universo o grupo espírita cresce por atrair fiéis criados como católicos ou "sem religião", mas não os pentecostais. Esses últimos quando deixaram sua igreja, foram para uma igreja protestante histórica ou se tornaram sem religião. Da mesma forma, a maior parte dos protestantes deixou sua igreja para se tornar também sem religião.

Nossos dados não permitem identificar o trânsito de indivíduos entre as diferentes igrejas dentro do campo protestante ou do campo pentecostal. Como dito anteriormente, quando um indivíduo criado pentecostal deixa o pentecostalismo, prefere ir para o protestantismo histórico (38\%) ou se declarar "sem religião" (31\%) a adotar religiões mediúnicas, ou seja, se tornar espírita kardecista $(0 \%)$ ou ir para religiões afro-brasileiras ( $0 \%)$. A pregação pentecostal acusa todas as religiões mediúnicas de demoníacas e certamente um indivíduo criado pentecostal terá muita dificuldade de se aproximar delas.

Observamos no EPS que os grupos religiosos que mais cresceram foram os que se destacam, segundo a literatura citada, por oferecer curas e dar sentido à doença e ao sofrimento: os espíritas kardecistas, em primeiro lugar, e, em segundo, os evangélicos (mais especificamente, os pentecostais). No entanto, como todas as religiões, de uma forma ou de outra, procuram superar e dar sentido ao sofrimento, analisaremos a seguir a associação entre a autopercepção de saúde (boa vs. ruim) e a variável "ter ou não ter religião" (Tabela 6). Procuraremos ainda associar a autopercepção de saúde ao "trânsito religioso", ou seja, à variável que distingue os que adotaram nova religião daqueles que abandonaram qualquer religião e também dos que permaneceram na religião na qual foram criados (Tabela 7). 


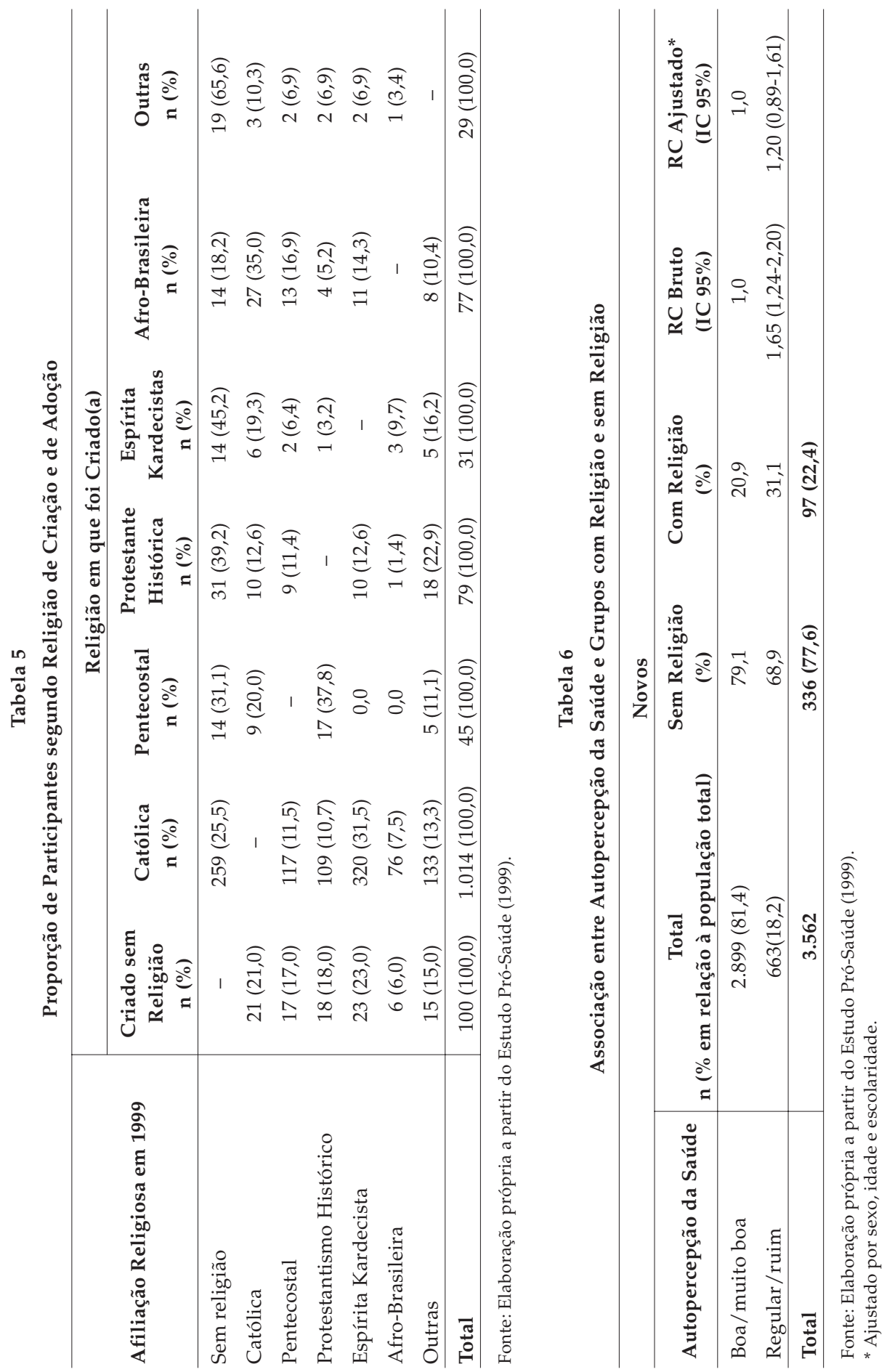

1260 DADOS - Revista de Ciências Sociais, Rio de Janeiro, vol. 59, no 4, 2016 
Saúde, Religião e Trânsito Religioso: Estudo Pró-Saúde

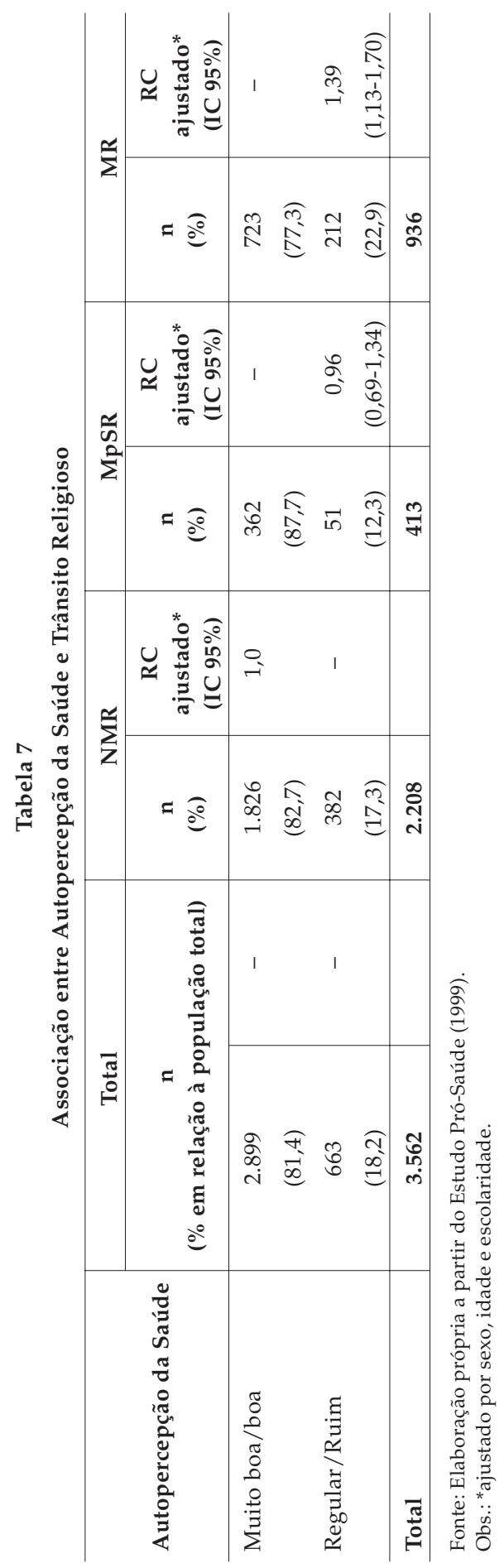

DADOS - Revista de Ciências Sociais, Rio de Janeiro, vol. 59, n 4, 2016 


\section{AUTOPERCEPÇÃO DE SAÚDE E RELIGIÃO}

Segundo Guimarães et al. (2012), a autopercepção de saúde é influenciada pelo gênero, idade e nível de escolaridade. As pessoas mais idosas têm mais problemas de saúde, por isso possuem uma pior autopercepção da saúde em comparação com pessoas mais jovens (Marcellini, 2002; Nunes, Barreto e Gonçalves, 2012). Em relação às mulheres, a principal explicação apontada para sua pior percepção do estado de saúde é o papel desempenhado por elas na sociedade, "que as leva a reconhecer a dor e o desconforto com mais facilidade do que os homens", como mostram Giatti e Barreto (2002). Vários estudos afirmam que o estrato social (nessa amostra se expressaria mais claramente no nível de instrução), interfere na autopercepção de saúde variáveis associam-se tanto à autopercepção da saúde como ao trânsito religioso (Souza et al., 2008; Nunes, Barreto e Gonçalves, 2012). Para avaliar a associação da autopercepção de saúde com o trânsito religioso propomos um modelo multinominal com ajuste estatístico por sexo, idade e escolaridade, já que as mesmas variáveis associam-se tanto à autopercepção da saúde como ao trânsito religioso.

Na Tabela 6, apresentamos um modelo multivariado entre a autopercepção da saúde e os grupos que relataram possuir religião (incluindo aí todas as religiões declaradas) e o grupo sem religião. Quando observamos a razão de chances ajustada para sexo, idade e escolaridade, não se verifica associação significativa entre a autopercepção regular ou ruim da saúde e os grupos supracitados.

Diferentemente, na Tabela 7 apresentamos o modelo multinominal utilizando a categoria não mudou de religião (NMR) como referência. A razão de chances para quem mudou para sem religião (MpSR) foi de 0,96 (IC $95 \%$ 0,7-1,3) e para quem mudou de religião a razão de chances foi de 1,4 (IC 95\%1,1-1,7). As pessoas que perceberam sua saúde como regular/ruim apresentam uma chance $40 \%$ mais elevada de ter mudado de religião (MR) quando comparado àquelas que percebem a saúde como muito boa/boa, independente das variáveis sociodemográficas (sexo, idade e escolaridade). No entanto, comparando as pessoas que mudaram para sem religião (MpSR) e aquelas que não mudaram de religião (NMR), não se verificou associação estatisticamente significantiva, embora haja um padrão de associação inversa. 
Podemos, no entanto, questionar se essa associação não ocorreria com todos que possuem religião ou apenas com alguma religião em especial. Portanto, na Tabela 8 buscamos identificar associações entre a autopercepção de saúde e afiliação religiosa, com similar modelo multinominal.

Observamos uma associação direta e estatisticamente significativa entre autopercepção regular ou ruim de saúde e espíritas kardecistas e adeptos de religiões afro-brasileiras, apesar dessa associação não ter sido observada na Tabela 6 para o conjunto que possui religião quando comparado com o que não possui.

Para verificar se havia diferença também quanto à associação da percepção de saúde e os grupos religiosos no interior do conjunto dos que declararam ter mudado de religião (conjunto significativamente associado à autopercepção regular e ruim, observada na Tabela 7), decidimos comparar a autopercepção de saúde entre os dois grupos religiosos que mais cresceram: novos kardecistas (nk) e novos pentecostais (np). Foi possível observar que o fato de ter pior autopercepção de saúde não aumenta as chances de afiliação ao kardecismo em comparação aos novos pentecostais quando ajustado por sexo, idade e escolaridade (Tabela 9).

Portanto, trajetórias de vida que incluiram mudança de identidade religiosa estiveram associadas à autopercepção de saúde como "regular" ou "ruim". Evidentemente, a autopercepção de saúde analisada foi declarada no momento da coleta de dados, realizada após mudança de identidade religiosa ocorrida em período não investigado pela pesquisa. No entanto, essa limitação não invalida a suposição de que essa autopercepção de saúde "regular ou ruim" já estivesse dada no momento da mudança de religião, fomentando a mudança, visto que estudos qualitativos prévios realizados nas últimas décadas (Neves, 1984; Mariz, 1994; Machado, 1996; Chesnut, 1997; Mafra, 2000, 2002; Medeiros, 2000; Mello e Oliveira, 2013, entre outros) relacionaram a busca de novas religiões a momentos de crise de saúde. Além disso, vários desses pesquisadores sugerem que muitas das curas não levam a uma superação total do problema de saúde, os indivíduos "curados" passam a conviver melhor com a doença, mas mantêm a consciência de que têm problemas de saúde (Mariz,1994; Mello e Oliveira, 2013, entre outros). Dessa forma, é provável que muitas das "curas religiosas" não impeçam que os indivíduos tenham uma autopercepção de saúde ao 

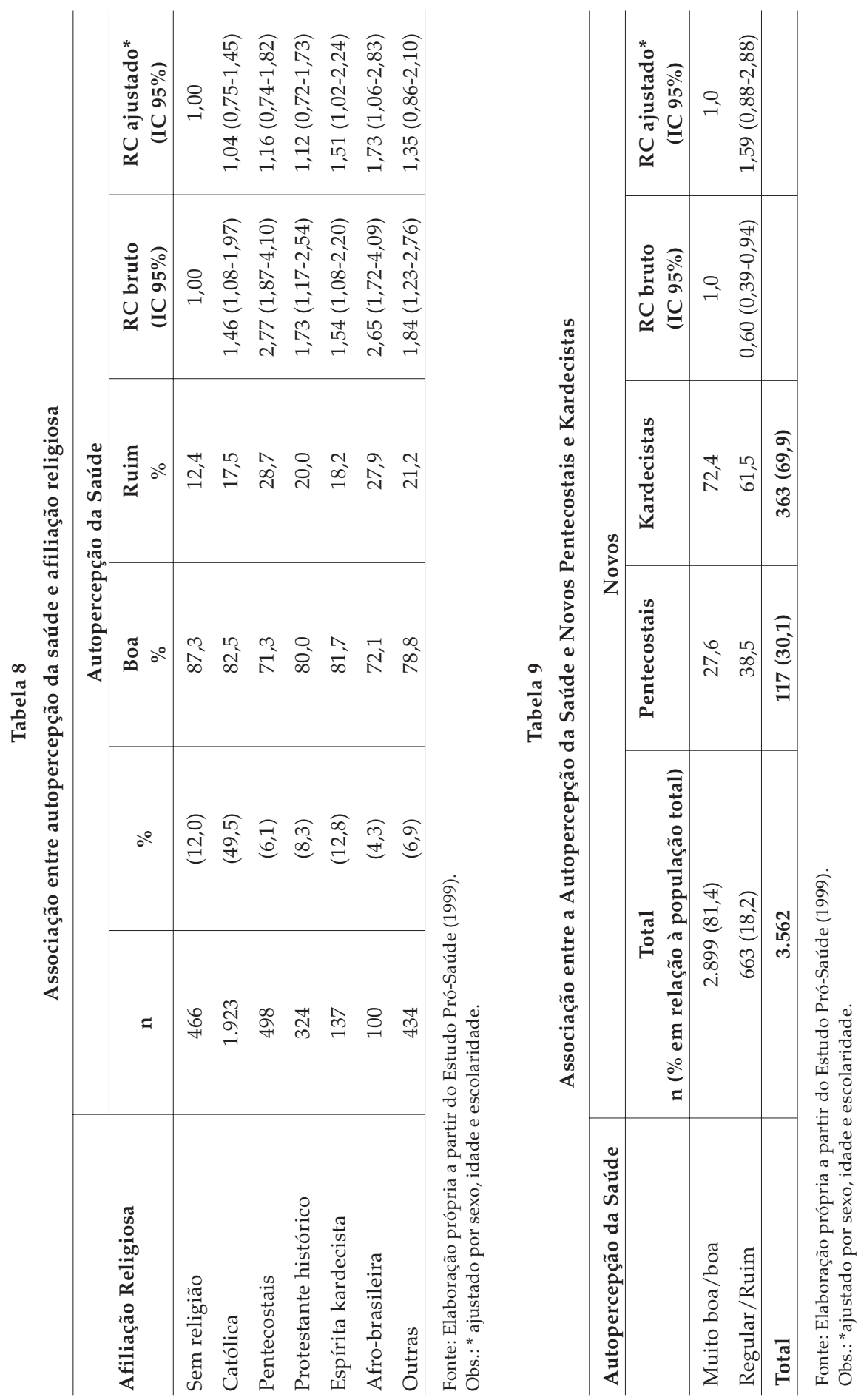

1264 DADOS - Revista de Ciências Sociais, Rio de Janeiro, vol. 59, no 4, 2016 
menos como "regular". Com essas considerações, não estamos negando que a pessoa não tenha encontrado a saúde que buscava na nova religião. Declarar uma autopercepção regular ou ruim de saúde não quer dizer que a pessoa se sente ou se considera de fato doente. Se as pessoas estavam trabalhando ${ }^{11}$, elas se percebiam como saudáveis ou curadas de alguma doença que por acaso já tiveram, no entanto reconhecem que têm propensão a adoecer. A "cura" pode ser um aprendizado de como conviver adequadamente com doenças.

\section{CONSIDERAÇÕES FINAIS}

Como salientamos no início deste artigo, nosso objetivo era analisar as direções do trânsito religioso e as características sociais dos que mudam de religião comparando com os que deixam de ter religião na população do EPS. Também nos propomos verificar a associação entre esses comportamentos e a autopercepção de saúde nessa população. Devido às caracteristicas socioeconômicas específicas da população de funcionários públicos estudada pelo EPS, o perfil religioso e a trajetória de mudança de religião registradas nessa pequisa se distinguiram daqueles observados à mesma época na população brasileira em geral. Comparando com os estudos citados que se baseiam em amostra nacional, observa-se que houve no EPS maior proporção de pessoas que mudaram de religião e também abandonaram qualquer religião. Os que deixaram de ter religião se distinguiam dos que mudaram de religião por serem mais jovens, solteiros ou separados, mais instruídos e com maior renda. Embora os dados ensejem mais discussões, focamos na associacão entre autopercepção de saúde e mudança de religião.

Comparando-se os dados da população estudada com o censo de 2000 do Brasil e do Rio de Janeiro, duas diferenças sobressaem: a proporção dos sem religião e de espíritas kardecistas. No entanto, a diferença mais notória foi, sem dúvida, o grande número de espíritas kardecistas, que superam os evangélicos em geral e os pentecostais, em particular. Enquanto na população geral, o grupo que mais crescia era o dos pentecostais, na amostra que analisamos era o dos espíritas kardecistas. A expressiva presença de espíritas kardecistas se relaciona com a idade, o gênero e o nível de instrução da população estudada. Como já apontado, na população brasileira, esse grupo religioso tende a ser relativamente mais feminino, mais velho e mais instruído. Esse resultado reforça o que tem sido sugerido em diversas pesquisas, tanto quali- 
tativas quanto quantitativas, sobre a associação entre as características sociodemográficas e novas identidades religiosas.

O grande número de espíritas kardecistas nos últimos censos pode também se relacionar a campanhas para que os indivíduos ligados a grupos kardecistas assumam uma identidade religiosa própria, rompendo com a tendência dos fiéis das religiões mediúnicas em geral de se identificarem como católicos e se tornarem invisíveis" em pesquisas dessa natureza (pesquisas quantitativas com questão fechada sobre religião). Os resultados do EPS sugerem que com essa nova atitude dos kardecistass omada ao envelhecimento e aumento do nivel de instrução da população brasileira, os censos nacionais continuem a verificar-se uma expansão do kardecismo, como foi observado em 2000 e 2010.

Em nosso estudo, a identidade religiosa espírita kardecista, e também o conjunto dos que declararam ter mudado de religião, estão positivamente associados à autopercepção regular ou ruim da saúde. Como os que mudaram de religião nessa amostra eram em sua maioria novos kardecistas, procuramos verificar se havia associacao mais significativa entre estes do que entre os novos pentecostais, não sendo observada, contudo, diferença relevante. Esta observação corrobora as sugestões de pesquisas qualitativas que afirmam que os que mudam de religião enfrentam problemas de saúde.

Considerando que as pessoas religiosas geralmente alegam terem sido curadas por sua fé, estudos internacionais sobre religião e saúde tendem a definir a religiao como a variável independente e saúde como a variável dependente a fim de estabelecer se a religião, e quais religiões, estariam positivamente associadas à saúde. Propomos aqui a relação inversa, ou seja, tomar a identidade religiosa, e também a "mudança de religião", como as variáveis dependentes. E o fazemos levando em conta as pesquisas qualitativas, que, em grande parte, atribuem a "cura" religiosa à ressignificação do sofrimento; ademais, a busca por nova religião tende a associar-se à procura de obter cura. Embora a religião possa estimular o indivíduo a lidar de maneira positiva com seus problemas e crises de saúde, ela não necessariamente ajuda a superar completamente uma condição de fragilidade mais geral e uma propensão mais intensa à doença, que poderia estar expressada na autopercepção de saúde regular ou ruim. Por outro lado, como tem sido ressaltado na literatura pertinente ao assunto, para manter a saúde, os 
individuos também procuram manter vinculação com o grupo religioso que os ajudou a ressignificar seu mal. Destacamos aqui a importância de estabelecer diálogos entre os resultados de surveys e pesquisas qualitativas, especialmente no estudo de questões como religião.

As pesquisas qualitativas sobre cura e religião indicam ainda que a "cura pela via religiosa" está relacionada a um cuidado da alma ou do espírito, o qual, por sua vez, exigiria frequentemente uma mudança de visão de mundo e estilo de vida, e uma adesão mais definitiva ao grupo religioso no qual a busca da cura foi bem-sucedida. Dessa forma, concluímos que, na população aqui analisada, o trânsito religioso esteve associado à busca e manutenção da saúde por parte daqueles que percebem a seu estado de saúde como regular ou ruim. Reconhecemos que há casos de curas eventuais, sem mudança de identidade religiosa, como é comum em pessoas que se submetem a "cirurgias" espirituais ou outros tratamentos. Apesar dessa possibilidade, o padrão geral dos discursos religiosos sobre doença e cura é que para manter a saúde o indivíduo deve aderir à religião que o curou. Portanto, para aqueles que enfrentam continuados problemas de saúde, a adesão à religião na qual se experimentou uma cura, pode ser comum. A persistência do problema de saúde pode levar a uma maior frequência e adesão ao grupo. Não se nega que haja outras motivações para a mudança de religião, mas nosso argumento é que grande parte da manutenção de uma identidade religiosa distinta daquela em que a pessoa foi criada estaria vinculada ao enfrentamento de problemas de saúde.

Por se tratar de um estudo transversal, há limitações para o estabelecimento de uma relação temporal entre a autopercepção da saúde e o trânsito religioso, como hipotetizada. Ainda que estudos qualitativos não indiquem uma provável "causalidade reversa", para investigar de modo mais sólido a hipótese em questão, evidências longitudinais serão necessárias.

(Recebido para publicação em fevereiro de 2016)

(Reapresentado em junho de 2016)

(Aprovado para publicação em outubro de 2016) 


\section{NOTAS}

1. Ver, por exemplo, os artigos que constituem os livros organizados por Teixeira e Menezes $(2009,2013)$, nos quais se discutem os dados sobre religião dos censos de 2000 e 2010, e os livros de Jacob et al $(2003,2006)$.

2. A prosperidade é entendida como um estado de bem estar amplo que não se reduz ao mero sucesso material. Em seu estudo com membros da Igreja Renascer, Maurício Serafim (2008) identifica essa dimensão do conceito de prosperidade adotado por seus pesquisados.

3. A relação entre o individualismo moderno e a religião é um tema clássico da pesquisa no tema, já trabalhado por Berger (1985), mas que tem sido revisto e ampliado tanto no contexto nacional (por exemplo, Prandi e Pierucci,1996; Pierucci, 2013 entre outros) como no internacional (por exemplo, Hervieu-Léger, 2008; Davie,1994, entre outros).

4. Utilizamos aqui o conceito de saúde similar ao adotado pela Organização Mundial de Saúde (OMS).

5. A saúde tem papel muito importante no kardecismo como tem mostrado a literatura especializada. Ver, entre outros, Cavalcanti (1983), Aubrée \& Laplantine (2009); Stoll, (2002); Lewgoy (2004) e Giumbelli (1997).

6. Tais como mortalidade (Sundquist e Johansson, 1997; Guimarães et al., 2012) e depressão e ansiedade nas duas semanas anteriores (Lima-Costa, Firmo e Uchôa, 2004).

7. De acordo com a Fundação Getulio Vargas (2010), a cidade do Rio de Janeiro tem sido considerada a capital brasileira menos católica e mesmo assim, em 2003 os católicos eram $57,07 \%$ da população. Em 2009, 10 anos após os dados do EPS, talvez chegasse a um pouco menos da metade; $49,83 \%$.

8. O mesmo ocorreu no censo do Rio de Janeiro e do Brasil como um todo em 2000 e 2010, os pentecostais são menos brancos. Pesquisas qualitativas apontam que tradicionalmente os que praticavam as religiões afro-brasileiras se diziam católicos, no entanto, nas últimas décadas um conjunto mais intelectualizado da liderança desses grupos tem rejeitado essa atitude. Esses líderes, que possuem discursos antissincréticos, atraem fiéis com nível de instrução e renda mais elevados, sendo em geral percentualmente mais brancos do que os pentecostais que tendem ser mais pobres e menos instruídos. Na nossa amostra é evidente a maior proporção de pessoas com nível de educação superior entre os das religiões de matriz africana quando comparados aos pentecostais.

9. Em Mariz e Machado (1996) pode se encontrar uma revisão dessa ampla bibliografia e reflexão sobre a maior proporção de mulheres praticantes em todas as expressões cristãs, especialmente pentecostalismo, mas também em quase todas as demais religiões, com exceção do islamismo e do judaísmo.

10. No trabalho de Almeida e Montero (2001, cujos dados eram de 1998) 26,5\% mudaram de religião e no de Fernandes e Pitta (2006, sobre dados de 2004) houve 23,5\% (esses valores incluem os que deixaram de ter religião).

11. Foram também entrevistados funcionários em licença médica, mas em pequeno número, o que não afetou esses resultados. 


\section{REFERÊNCIAS BIBLIOGRÁFICAS}

ALMEIDA, Ronaldo de; MONTERO, Paula. (2001), "Trânsito Religioso no Brasil". São Paulo em Perspectiva, vol.15, no 3, pp. 92-100.

AMARAL, Leila. (2000), Carnaval da Alma: Comunidade, Essência e Sincretismo na Nova Era. Petrópolis, Vozes.

AUBRÉE, Marion; LAPLANTINE, François. (2009), A Mesa, o Livoro e os Espiritos. Gênese, Evolução e Atualidade do Movimento Social Espírita entre França e Brasil. Maceió, EdUFAL.

BAILIS, Dan. (2003), “Two Views of Self-rated General Health Status”. Social Science \& Medicine, vol. 56, no 2, pp. 203-217.

BERGER, Peter. (1985), O Dossel Sagrado: Elementos para uma Teoria Sociológica da Religião. São Paulo, Paulinas.

BONFATTI, Paulo. (2000), A Expressão Popular do Sagrado: Uma Análise Psico-antropológica da Igreja Universal do Reino de Deus. São Paulo, Paulinas.

CARRANZA, Brenda. (2000), Renovação Carismática Católica. Origens, Mudanças e Tendências. Aparecida, Santuário.

CAVALCANTI, Maria Laura Viveiros de Castro. (1983), O Mundo Invisível: Cosmologia, Sistema Ritual e Noção de Pessoa no Espiritismo. Rio de Janeiro, Zahar.

CHESNUT, Andrew. (1997), Born Again in Brazil. The Pentecostal Boom and the Pathogens of Poverty. London, Rutgers University Press.

DAVIE, Grace. (1994), Religion in Britain since 1945. Believing without Belonging. Blackwell, Oxford.

ELLISON, Christopher G. (1991), "Religious Involvement and Subjective Well-being”. Journal of Health and Social Behavior, vol. 32, pp. 80-99.

FAERSTEIN, Eduardo et al. (2005), “Estudo Pró-Saúde: Características Gerais e Aspectos Metodológicos". Revista Brasileira de Epidemiologia, vol. 4, no 8, pp. 454-466.

FERNANDES, Silvia R. Alves; PITTA, Marcelo. (2006), “Mapeando as Rotas do Trânsito Religioso no Brasil". Religião e Sociedade, vol. 26, no 2, pp. 120-154.

FERRETI, Mundicarmo. (2003), “Religiões Afro-brasileiras e Saúde: Diversidade e Semelhanças". Anais do Seminário Nacional: Religiões Afro-Brasileiras e Saúde. São Luiz do Maranhão.

FONSECA, Silvio Aparecido et al. (2008), "Percepção de Saúde e Fatores Associados em Industriários de Santa Catarina, Brasil”. Caderno de Saúde Publica, vol. 24, no 3, pp. 567-576.

FRESTON, Paul. (1994), "Breve História do Pentecostalismo Brasileiro", in A. Antoniazzi (ed.), Nem Anjos nem Demônios: Interpretações Sociológicas do Pentecostalismo. Petrópolis, Vozes.

FRY, Peter; HOWE, Gire Nigel. (1975), “Duas Respostas à Aflição. Umbanda e Pentecostalismo". Debate e Crítica, no 6, pp. 75-94.

DADOS - Revista de Ciências Sociais, Rio de Janeiro, vol. 59, no 4, 2016 
FUNDAÇÃO GETUliO VARGAS. (2010), Pesquisa de Orçamentos Familiares 2008-2009. Disponível em <http://www.fgv.br/ibrecps/BU/despesas/POF1_domicilio.pdf $>$. Acesso em 5/8/2014.

. (2011), Novo Mapa das Religiões. Disponível em http://www.cps.fgv.br/ cps/bd/rel3/REN_texto_FGV_CPS_Neri.pdf. Acesso em 5/8/2014.

GIATTI, Luana; BARRETO, Sandhi. (2002), "Trabalho Feminino e Envelhecimento na Terceira Idade". Ciência e Saúde, vol. 7, no 4, pp. 825-839.

GIUMBELLI, Emerson. (1997), O Cuidado dos Mortos: Uma História da Condenação e Legitimação do Espiritismo. Rio de Janeiro, Arquivo Nacional.

GREENFIELD, Sidney M. (1992), “O Corpo como uma Casca Descartável: As Cirurgias do Dr. Fritz e o Futuro das Curas Espirituais". Religião e Sociedade, vo1.1, no 16, pp.136-145.

GUIMARÃES, Joanna M. Nery et al. (2012), "Association between Self-rated Health and Mortality: 10 Years Follow-up to the Pró-Saúde Cohort Study". BMC Public Health, vol. 12, no 676, pp. 2-10.

HERVIEU-LÉGER, Daniele. (2008), O Peregrino e o Convertido. Petrópolis, Vozes.

IDLER, Ellen; BENYAMINI Yael. (1997), “Self-Rated Health and Mortality: A Review of Twenty-Seven Community Studies". Journal of Health and Social Behavior, vol. 38, no 1, pp. 21-37.

JACOB, Cesar Romero et al. (2003), Atlas da Filiação Religiosa e Indicadores Sociais no Brasil. Rio de Janeiro, PUC-Rio.

JACOB, Cesar Romero et al. (2006), Religião e Sociedade em Capitais Brasileiras, Rio de Janeiro, PUC-Rio.

JYLHÄ, Marja et al. (1998), "Is Self-rated Health Comparable across Cultures and Genders?". Journal of Gerontology, vol. 53B, no 3, pp. S144-S152.

KAPLAN, George; CAMACHO, Terry. (1983), "Perceived Health and Mortality: A Nine-Year Follow-up of the Human Population Laboratory Cohort". American Journal of Epidemiology, vol.117, no 3, pp. 292-304.

KOENIG, Harold G. (2001), "Religion and Medicine III: Developing a Theoretical Model". The International Journal of Psychiatry in Medicine, vol. 31, no 2, pp. 199-216.

LEHMANN, David. (2012), “Hope and Religion”. Estudos Avançados, vol. 26, no 75, pp. 219-236.

LEVIN, Jeff. (1996), “How Religion Influences Morbidity and Health: Reflections on Natural History, Salutogenesis and Host Resistance". Social Science \& Medicine, vol. 43, no 5 , pp. 849-864.

LEWGOY, Bernardo. (2004), O Grande Mediador: Chico Xavier e a Cultura Brasileira. Brasília, Edusc.

LIMA-COSTA, Maria Fernanda; FIRMO, Josélia; UCHOÂ, Elizabeth. (2004), “The Structure of Self-rated Health among Older Adults: The Bambuí Health and Ageing Study (BHAS)". Revista de Saúde Pùblica, vol 38, no 6, pp. 827-834. 
LUZ, Madel. T. (2005), “Cultura Contemporânea e Medicinas Alternativas: Novos Paradigmas em Saúde no Fim do Século XX". Physis: Revista de Saúde Coletiva, vol. 15, Suppl, pp. 145-176.

MACHADO, Maria das Dores Campos. (1996), Carismáticose Pentecostais. Adesão religiosa na Esfera Familiar. São Paulo, Anpocs/Editora Autores Associados.

MAFRA, Clara. (2000), “Relatos Compartilhados: Experiências de Conversão ao Pentecostalismo entre Brasileiros e Portugueses". Mana, vol. 6, no 1, pp. 57-86. . (2002), Na Posse da Palavra. Religião, Conversão e Liberdade Pessoal em Dois Contextos Nacionais. Lisboa, Imprensa de Ciências Sociais.

MANDERBACKA, Kristiina; LUNDBERG, Olle; MARTIKAINEN, Pekka. (1999), "Do Risk Factors and Health Behaviours Contribute to Self-ratings of Health?". Social Science \& Medicine, vol. 48, no 12, pp. 1713-20.

MARCELLINI, Fiorella. (2002), "Health Perception of Elderly People: The Results of a Longitudinal Study". Archives Gerontology Geriatrics, Suppl, pp. 292-304.

MARIANO, Ricardo. (1999), Neopentecostais: Sociologia do Novo Pentecostalismo no Brasil. São Paulo, Edições Loyola Jesuítas.

MARIZ, Cecília Loreto. (1994), Coping with Poverty: Pentecostals and Christian Base Communities in Brazil. Philadelphia, PA, Temple University Press.

; MACHADO, Maria das Dores Campos. (1994), "Pentecostalismo e a Redefinição do Feminino". Religião e Sociedade, vol. 17, no 1, pp.140-159.

MARTIKAINEN, Pekka; ARPO, Aromaa; HELIOVAARA, Match. (1999), "Reliability of Perceived Health by Sex and Age". Social Science \& Medicine, vol. 48, no 8, pp. 1117-1122.

MARTINS, Andréa M. de Barros Lima; BARRETO, Sandhi Maria e PORDEUS, Isabela Almeida. (2009), “Auto-avaliação de Saúde Bucal em Idosos: Análise com Base em Modelo Multidimensional”. Cadernos de Saúde Pública, vol. 25, no 2, pp. 421-435.

MAUÉS, Raimundo Heraldo. (2004), “A Renovação Carismática e a Cura de um Espaço Comunitário". Revista Anthropológicas, vol. 15, no 1, pp.79-98.

;SANTOS, Kátia Bárbara; SANTOS, Marinéa Carvalho. (2002), “Em Busca de Cura: Ministros e Doentes na Renovação Carismática Católica". Revista Anthropológicas, vol. 13, no 1, pp. 131-154.

MEDEIROS, Kátia Maria Cabral. (2000), O Prazer de Jesus é Curar: O Sentido da Cura no Discurso Pentecostal da Assembleia de Deus. Dissertação (Mestrado em Psicossociologia de Comunidades e Ecologia Social). Universidade Federal do Rio de Janeiro, Rio de Janeiro.

MELLO, Márcio Luiz; OLIVEIRA, Simone Santos. (2013), “Saúde, Religião e Cultura: Um Diálogo a partir das Práticas Afro-brasileiras". Saúde e Sociedade, vol. 22, no 4, pp. 1024-1035.

MINAYO, Maria Cecília de Souza. (1988), "Saúde-doença: Uma Concepção Popular da Etiologia". Cadernos de Saúde Pública, vol. 4, no 4, pp. 363-381.

MONTERO, Paula. (1985), Da Doença a Desordem: A Magia na Umbanda. Rio de Janeiro, Edições Graal.

DADOS - Revista de Ciências Sociais, Rio de Janeiro, vol. 59, no 4, 2016 
NEVES, Delma Pessanha. (1984), As “Curas Milagrosas" e a Idealização da Ordem Social. Niterói, CEUFF.

NOVAES, Regina. (2013), “Jovens sem Religião: Sinais de outros Tempos”, in F. Teixeira; R. Menezes (orgs.), Religiões em Movimento: O Censo de 2010. Petrópolis, Vozes, pp. 175-190.

NUNES, Ana Paula Nogueira; BARRETO, Sandhi Maria; GONÇALVES, Luana Giatti. (2012), "Relações Sociais e Autopercepção da Saúde: Projeto Envelhecimento e Saúde". Revista Brasileira de Epidemiologia, vol.15, no 2, pp. 415-428.

PARGAMENT, Kenneth et al. (1988), "Religion and the Problem-solving Process: Three Styles of Coping". Journal for the Scientific Study of Religion, vol. 27, no 1, pp. 90-104.

PIERUCCI, Antônio Flávio. (2013), “O Crescimento da Liberdade Religiosa e o Declínio da Religião Tradicional: A Propósito do Censo de 2010", in F. Teixeira; R. Menezes (orgs.), Religiões em Movimento: O Censo de 2010. Petrópolis, Vozes.

PRANDI, Reginaldo. (1996), Um Sopro do Espírito São Paulo, EDUSP.

; PIERUCCI, Antonio F. (1996), A Realidade Social das Religiões no Brasil. São Paulo, Hucitec.

QUESNEL-VALLÉ, Amélie. (2007), "Self-rated Health: Caught in the Crossfire of the Quest for "True' Health?". International Journal of Epidemiology, vol. 36, no 6, pp. 1161-1164.

RIBEIRO, Carlos Antonio Costa. (2011), “Desigualdade de Oportunidades e Resultados Educacionais no Brasil". DADOS - Revista de Ciências Sociais, vol. 54, no1, pp.41-87.

SERAFIM , Maurício. (2008), Sobre esta Igreja Edificarei minha Empresa: Organizações Religiosas e Empreendedorismo. Tese (Doutorado em Administração de Empresas), Fundação Getulio Vargas São Paulo.

SOUZA, Mirian Carvalho et al. (2008), Auto-avaliação de Saúde e Limitações Físicas Decorrentes de Problemas de Saúde". Revista de Saúde Pública, vol. 42, noㄴ, pp. 741-749.

SUNDQUIST Eric; JOHANSSON, S. E. (1997), Self Reported Poor Health and Low Educational Level Predictors for Mortality: A Population Based Follow up Study of 39,156 People in Sweden. Journal of Epidemiology Community Health, vol. 51, no 1, pp. $35-40$.

STOLL, Sandra Jacqueline. (2002), “Religião, Ciência ou Auto-ajuda?: Trajetos do Espiritismo no Brasil. Revista de Antropologia, vol. 45, no 2, pp. 361-402.

STEIL, Carlos Alberto. (2004), “Renovação Carismática Católica: Porta de Entrada ou de Saída do Catolicismo? Uma Etnografia do Grupo São José, Porto Alegre (RS)". Religião \& Sociedade, vol. 24, no 1, pp. 11-36.

TEIXEIRA, Faustino. (2013), “O Censo de 2010 e as Religiões no Brasil: Um Esboço de Apresentação", in F. Teixeira e R. Menezes (orgs.), Religiões em Movimento: O Censo de 2010. Petrópolis, Vozes.

; MENEZES, Renata. (2006), As Religiões do Brasil: Continuidades e Rupturas. Petrópolis, Vozes.

WEBER, Max. (2002), “A Psicologia das Religiões Mundiais”, in H. Gerth; W. Mills (eds.), Ensaios de Sociologia. Rio de Janeiro, LTC. 


\title{
RESUMO
}

\author{
Saúde, Religião e Trânsito Religioso: O Estudo Pró-Saúde
}

Embora pesquisas qualitativas apontem para uma relação entre mudança de religião e busca por saúde e superação de doenças e do sofrimento em geral, há pouca produção de dados quantitativos sobre o tema. Esse artigo pretende preencher em parte essa lacuna analisando os resultados de um estudo epidemiológico com funcionários públicos no Rio de Janeiro (Estudo Pró-Saúde) em 1999. Dos 3.562 indivíduos pesquisados, $62 \%$ mantiveram a religião em que foram criados, $26 \%$ mudaram de religião, e $12 \%$ mudaram para "sem religião". O trânsito religioso, variável derivada da comparação entre religião de criação e religião declarada à época da pesquisa, foi marcado por crescimento de kardecistas e do grupo "sem religião". Para verificar a associação entre a variável autopercepção da saúde e as variáveis identidade religiosa e trânsito religioso, foi realizada uma análise estatística ajustada por variáveis sociais e demográficas. Observou-se uma chance $40 \%$ mais elevada de uma autopercepção da saúde "regular ou ruim" estar associada à mudança de religião, quando comparada à autopercepção de saúde "boa ou muito boa", independentemente de idade, sexo e escolaridade.

Palavras-chave: religião; trânsito religioso; autopercepção da saúde; Estudo Pró-Saúde

\section{ABSTRACT \\ Health, Religion, and Religious Conversion: The Pro-Health Study}

Although qualitative studies point to a link between religious conversion and a person's heightened concern for their own health and the overcoming of illness and suffering in general, scant quantitative research has been produced on the subject. This article aims to address such an absence by analyzing the results of an epidemiological study carried out on civil servants in Rio de Janeiro in 1999 known as the Estudo Pró-Saúde [Pro-Health Study]. Of the 3,562 individuals surveyed, $62 \%$ still identified with the religion they were raised with, $26 \%$ had converted to another religion, and $12 \%$ considered themselves to be of "no religion". Religious conversion - a variable derived by means of comparing a person's religion during their upbringing with their religion declared during the study - was marked by means of a growth in Spiritism and in the "no religion" group. In order to verify the association between the variable of self-reported health status and the variables of religious identify and religious conversion, a statistical analysis was carried out adjusted according to social and demographic variables. Subjects were $40 \%$ more likely to report their own health status as "average or poor" before undergoing a religious conversion, compared to a self-reported status of "good or very good", regardless of age, gender, and level of education.

Key words: religion; religious conversion; self-reported health status; Pro-Health Study 


\section{RÉSUMÉ}

\section{Santé, Religion et Transit Religieux: L'Étude Pró-Saúde}

Bien que les recherches qualitatives mettent en évidence une relation entre changement de religion et quête de santé et de dépassement des maladies et de la souffrance en général, encore peu de données quantitatives ont été produites sur le sujet. Cet article entend combler cette lacune en analysant les résultats d'une étude épidémiologique menée auprès de fonctionnaires de Rio de Janeiro (Étude Pró-Saúde) en 1999. Sur les 3562 individus de l'étude, 62\% ont conservé la religion dans laquelle ils avaient été élevés, tandis que $26 \%$ en ont changé et $12 \%$ se sont tournés vers l'athéisme ("sans religion"). Le transit religieux, une variable calculée à partir de la comparaison entre religion familiale et religion déclarée à l'époque de la recherche, a été marqué par l'augmentation du nombre de spirites kardecistes et de "sans religion". Afin de corroborer l'association entre la variable "auto-perception de la santé" et les variables d'identité et de transit religieux, nous avons réalisé une analyse statistique ajustée par des variables sociales et démographiques. On a pu observer $40 \%$ de chance supplémentaire de l'occurrence du lien entre auto-perception de la santé "normale ou mauvaise" et un changement de religion, en comparaison avec le lien avec une auto-perception de la santé "bonne ou très bonne", indépendamment de l'âge, du sexe et du niveau d'études.

Mots-clés: religion; transit religieux; auto-perception de la santé; Étude Pró-Saúde

\section{RESUMEN}

\section{Salud, Religión y Tránsito Religioso: El Estudio Pro-Salud}

Si bien investigaciones cualitativas indican una relación entre el cambio de religión y la búsqueda de salud y superación de enfermedades y del sufrimiento en general, hay poca producción de datos cuantitativos sobre el tema. El objetivo de este artículo es cubrir en parte esa brecha, analizando los resultados de un estudio epidemiológico con funcionarios públicos en Río de Janeiro (Estudio Pro-Salud) en 1999. De los 3.562 individuos encuestados, el 62\% mantuvieron la religión en que se criaron, el 26\% cambiaron de religión y el 12\% cambiaron a "sin religión". El tránsito religioso, variable derivada de la comparación entre religión de crianza y religión declarada a la época de la investigación, fue marcado por el crecimiento de kardecistas y del grupo "sin religión". Para verificar la asociación entre la variable autopercepción de la salud y las variables identidad religiosa y tránsito religioso, se realizó un análisis ajustado por variables sociales y demográficas. Se observó una posibilidad el $40 \%$ más elevada de que una autopercepción de la salud "regular o mala" esté asociada al cambio de religión, frente a la autopercepción de salud "buena o muy buena", independientemente de la edad, el sexo y el nivel de educación.

Palabras clave: religión; tránsito religioso; autopercepción de la salud; Estudio Pro-Salud 